Jurnal ABDIMAS INDEPENDEN

Vol. 1, No. 2, November 2020

\title{
PENYUSUNAN ANGGARAN KAS KB/TK PURNAMA DI DESA KARANG GENTENG PAGUTAN
}

\author{
Bambang, M.Ali Fikri, Baiq Anggun Hilendri Lestari, Widia Astuti, Robith \\ Hudaya \\ Jurusan Akuntansi - Universitas Mataram, \\ bambangunram@gmail.com
}

\begin{abstract}
ABSTRAK
Anggaran kas adalah anggaran yang memerinci taksiran penerimaan dan pengeluaran uang tunai dalam suatu kurun masa yang akan datang sebagai alat untuk memelihara likuiditas. Anggaran kas memiliki peran yang penting dalam mengendalikan kas. Penyusunan anggaran kas akan membantu organisasi dalam mempersiapkan keputusan pembelanjaan berjangka pendek atau berjangka panjang, menentukan posisi kas pada berbagai waktu, memperkirakan kemungkinan surplus atau defisit, bahkan dapat berfungsi sebagai dasar penilaian terhadap ralisasi pengeluaran kas yang sebenarnya.Pihak manajemen sekolah dituntut mampu mengelola dana yang tersedia secara efisien dan efektif, sehingga pola perencanaan yang matang perlu dilakukan, diantaranya tercermin dalam penyusunan anggaran kas sekolah. Pihak pengelola KB/TK PURNAMA belum mampu menyusun anggaran kas secara rinci mengenai semua jumlah kas dan perubahan-perubahannnya dari waktu ke waktu selama periode tertentu dimasa yang akan datang, baik perubahan yang berupa penerimaan maupun pengeluaran. Terkendala juga oleh kompetensi sumber daya manusia yang memiliki kemampuan tentang hal tersebut. Merujuk pada permasalahan yang ada perlu dilakukan pendampingan penyusunan angggaran kas. Melalui kegiatan pengabdian pengelola KB/TK PURNAMA memiliki pengetahuan dibidang anggaran khususnya anggaran kas dan pembukuan serta dapat langsung diaplikasikan dalam penyusunan anggaran kas dengan didukung pembukuan yang baik dan benar.
\end{abstract}

Kata Kunci : Penyusunan Anggaran Kas

\begin{abstract}
A cash budget is a budget that details the estimated cash receipts and disbursements in a future period as a tool to maintain liquidity. Cash budgets have an important role in controlling cash. The preparation of a cash budget will assist the organization in preparing short-term or long-term spending decisions,
\end{abstract}


determine the cash position at various times, estimate the possibility of a surplus or deficit, and can even serve as a basis for evaluating the actual cash expenditure realization. School management is required to be able to manage the funds that are available efficiently and effectively, so that a careful planning pattern needs to be done, including reflected in the preparation of the school cash budget. The management of KB / TK PURNAMA has not been able to compile a detailed cash budget regarding all cash amounts and their changes from time to time during certain periods in the future, both changes in the form of revenues and expenses. Also constrained by the competence of human resources who have the ability to do so. Referring to the existing problems, assistance in the preparation of cash budgets is necessary. Through community service activities, the manager of KB / TK PURNAMA has knowledge in the field of budgeting, especially cash budgets and bookkeeping and can be directly applied in cash budgeting supported by good and correct bookkeeping.

Keywords: Preparation of Cash Budget

\section{PENDAHULUAN}

Anggaran kas adalah anggaran yang memerinci taksiran penerimaan dan pengeluaran uang tunai dalam suatu kurun masa yang akan datang sebagai alat untuk memelihara likuiditas. Anggaran kas memiliki peran yang penting dalam mengendalikan kas. Penyusunan anggaran kas akan membantu organisasi dalam mempersiapkan keputusan pembelanjaan berjangka pendek atau berjangka panjang, menentukan posisi kas pada berbagai waktu, memperkirakan kemungkinan surplus atau defisit, bahkan dapat berfungsi sebagai dasar penilaian terhadap ralisasi pengeluaran kas yang sebenarnya.

Permendiknas Nomor 58 Tahun 2009 Pasal 1 menetapkan bahwa standar pendidikan anak usia dini meliputi pendidikan formal dan nonformal yang terdiri atas: 1) standar tingkat pencapaian perkembangan; 2) standar pendidik dan tenaga kependidikan; 3) standar isi, proses, dan penilaian; dan 4) standar sarana dan prasarana, pengelolaan, dan pembiayaan. Merujuk pada permendiknas tersebut, dapat disimpulkan bahwa ketersediaan anggaran sekolah yang memadai merupakan hal yang penting. Pihak manajemen sekolah dituntut 


\section{Jurnal ABDIMAS INDEPENDEN}

Vol. 1, No. 2, November 2020

mampu mengelola dana yang tersedia secara efisien dan efektif, sehingga pola perencanaan yang matang perlu dilakukan, diantaranya tercermin dalam penyusunan anggaran kas sekolah.

Pihak pengelola KB/TK PURNAMA belum mampu menyusun anggaran kas secara rinci mengenai semua jumlah kas dan perubahan-perubahannnya dari waktu ke waktu selama periode tertentu dimasa yang akan datang, baik perubahan yang berupa penerimaan maupun pengeluaran. Terkendala juga oleh kompetensi sumber daya manusia yang memiliki kemampuan tentang hal tersebut. Merujuk pada permasalahan yang ada perlu dilakukan pendampingan penyusunan angggaran kas.

\section{METODE KEGIATAN}

Metode yang digunakan untuk mencapai target luaran adalah metode partisipatif, yaitu suatu metode pembelajaran yang menempatkan peserta pengabdian sebagai pemain utama dalam setiap proses pembelajaran. Komponen pembelajaran ini mencakup dua hal yaitu pertama penyampaian materi dengan ceramah dan diskusi, serta latihan/praktik yang merupakan aplikasi dari pengetahuan yang sudah diperoleh.

\section{HASIL DAN PEMBAHASAN}

Hasil pengabdian penyusunan anggaran kas pada KB/TK Purnama dapat diuraikan sebagai berikut:

1. Terdapat 5 orang Guru, 1 orang guru merangkap sebagai kepala sekolah, dan 2 orang lagi merangkap sebagai bagian administrasi/pembukuan.

2. Turun lapangan pertama pada tanggal 10 Oktober 2019, kami melakukan identifikasi pencatatan dan laporan yang sudah disusun oleh manajemen KB/TK Purnama, meliputi: 
a. Buku catatan penerimaan dan pengeluaran harian. Buku ini berisi catatan secara kronologis transaksi penerimaan dan pengeluaran setiap hari (merupakan rincian uang masuk dan keluar)

b. Buku catatan pembayaran SPP. Berisi rincian nama-nama siswa yang sudah membayar spp

c. Buku pembantu pajak. Berisi catatan rincian jumlah pajak yang sudah dibayarkan

d. Buku kas umum. Berisi rekapan jumlah penerimaan dan pengeluaran dari buku kas harian. Namun buku ini belum disusun secara rutin.

e. Laporan realisasi penggunaan dana. Berisi pertanggungjawaban penggunaaan dana bantuan dari pemerintah (realisasi penggunaan dana dari setiap penerimaan).

3. Berdasarkan hasil wawancara dengan kepala sekolah menyatakan bahwa belum melakukan penyusunan anggaran, dan menyambut positif atas kegiatan pengabdian tersebut.

4. Turun lapangan kedua pada tanggal 11 Oktober 2019 tim pengabdian memberikan sosialisasi tentang materi penganggaran, mulai dari pentingnya penggunaan anggaran sampai asistensi langkah-langkah penyusunan anggaran. Pada pertemuan tersebut tim pengabdian bersama dengan 5 orang guru yang ada mencoba untuk mengidentifikasi jenis-jenis penerimaan dan pengeluaran pada KB/TK Purnama, antara lain:

a. Jenis-jenis penerimaan:

- Penerimaaan uang pendaftaran

- Penerimaan penjualan seragam

- Penerimaan SPP

- Penerimaan sumbangan

- Penerimaan lain-lain 


\section{Jurnal ABDIMAS INDEPENDEN}

Vol. 1, No. 2, November 2020

b. Jenis-jenis pengeluaran:

- Honor pendidik/guru

- Inseftif pengelola

- Pembelian seragam

- Pembelian majalah

- Pembelian bahan habis pakai

- Pembelian makanan tambahan untuk siswa

- Pembelian ATK dan fotocopy

- Transportasi tenaga medis

Berdasarkan jenis-jenis penerimaan dan pengeluaran tersebut pihak manajemen KB/TK Purnama berkomitmen untuk menyusun anggaran tahun 2020. Penyusunan anggaran bisa diperinci untuk setiap triwulan, sehingga lebih mudah untuk melakukan evaluasi terhadap kinerja secara bulanan berdasarkan anggaran yang telah disusun.
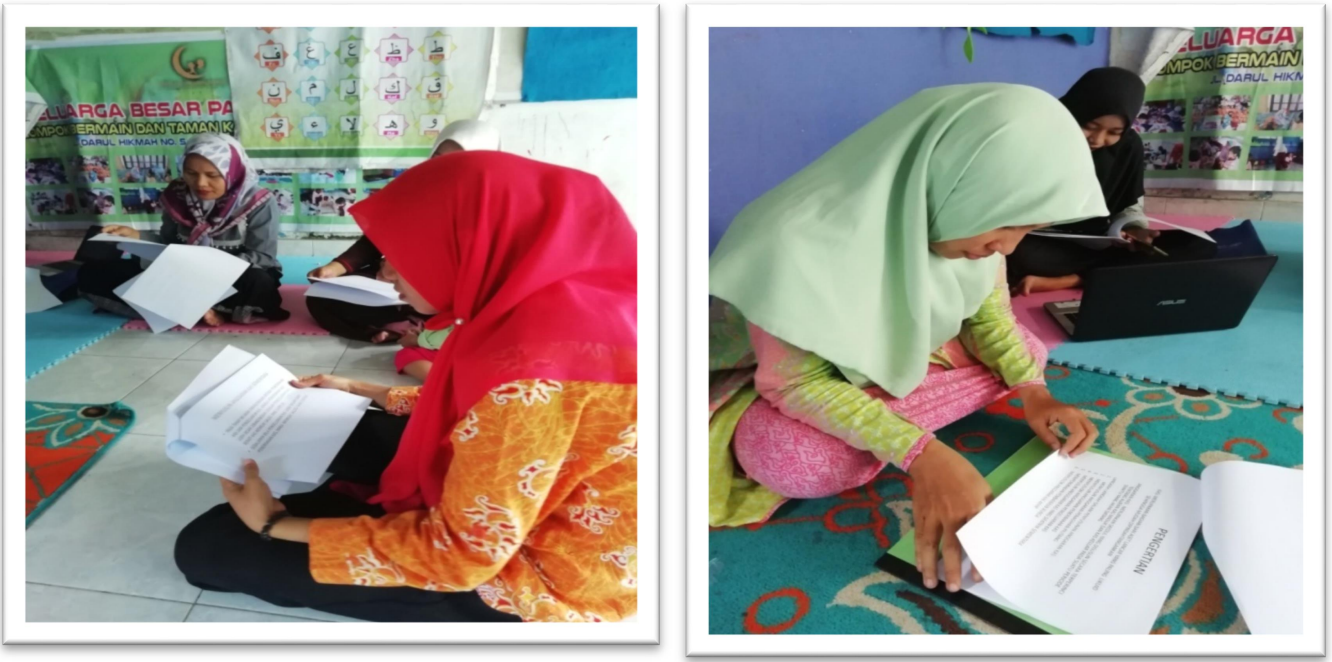

Gambar: Penyuluhan Anggaran Kas oleh Tim Pengabdian 

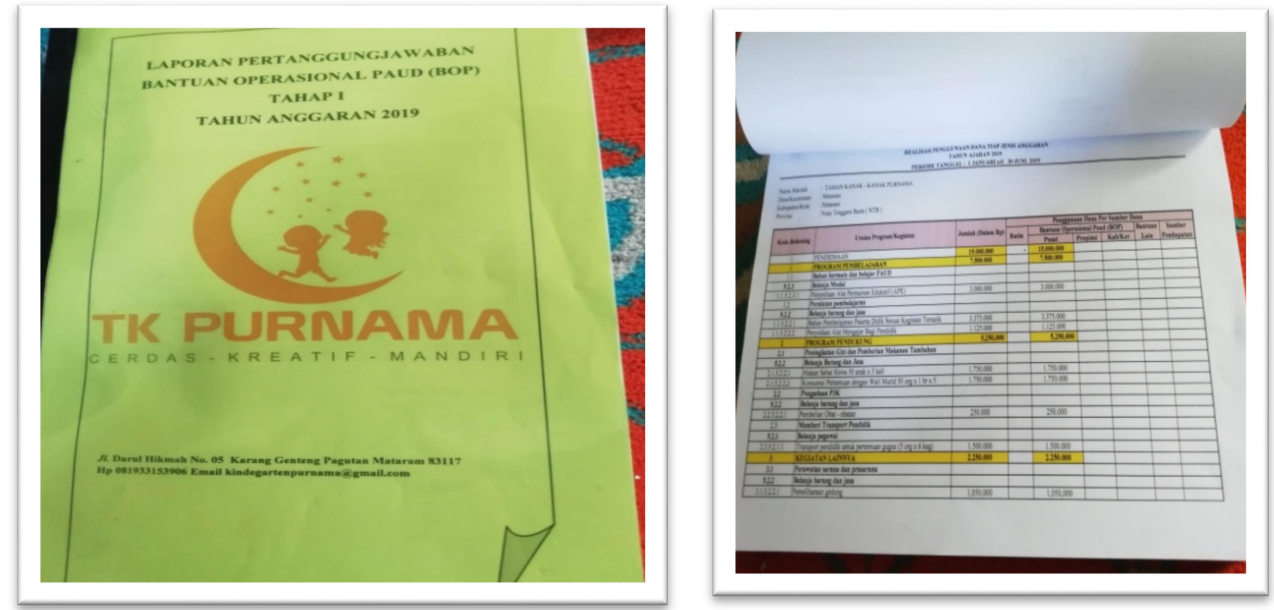

Gambar: Laporan Pertanggungjawaban TK Purnama

\section{KESIMPULAN DAN SARAN}

\section{Kesimpulan}

1. Pengabdian penyusunan anggaran kas pada KB/TK Purnama berjalan lancar dan mendapat tanggapan yang antusias dari peserta.

2. Dengan kegiatan pengabdian ini peserta memperoleh tambahan pengetahuan tentang penyusunan anggaran khususya dan makanisme pecatatan pada buku kas umum

Saran

1. Perlu melakukan penyusunan buku kas umum secara rutin

2. Perlu menyusun angggaran kas, sehingga bisa digunakan sebagai dasar untuk mengevaluasi kinerja keuangan.

\section{UCAPAN TERIMA KASIH}

Penulis mengucapkan terima kasih kepada Fakultas Ekonomi dan Bisnis seta Lembaga Pengabdian Kepada Masyarakat Universitas Mataram atas dukungan dana terhadap pengabdian ini. Tak lupa pula kami ucapkan terima kasih kepada pegelola dan guru KB/TK Purnama di Desa Karang Genteng, Pagutan atas partisipasinya dalam kegiatan pengabdian ini. 


\section{Jurnal ABDIMAS INDEPENDEN}

Vol. 1, No. 2, November 2020

\section{DAFTAR PUSTAKA}

Adisaputro, Gunawan. 2010. Anggaran Perusahaan. BPFE, Yogyakarta

Hansen \& Mowen. 2017. Akuntansi Manajerial. Salema Empat, Jakarta

Kusmianto. 2018. Peran serta masyarakat dalam pembiayaan Pendidikan Anak Usia Dini (PAUD). repository.uksw.edu

https://www.jurnal id. 2018

https://www. dictio.id ekonomi\&bisnis akuntansi 